\section{KNJIŽNICA STUDIJSKOG CENTRA SOCIJALNOG RADA 1994.-2013.: RAZVOJ PREMA SUVREMENOJ KNJIŽNICI} SAŽETAK

$U$ radu se prikazuje razvoj knjižnice Studijskog centra socijalnog rada u razdoblju 1994.-2013. Prate se promjene u načinu rada knjižnice uvjetovane kvantitativnim i kvalitativnim promjenama u samoj ustanovi. Posebice se naglasak stavlja na proces informatizacije knjižnice, koji je inicirao mnoge druge promjene u načinu rada. Nadalje se prati proces profesionalne izobrazbe knjižničara, te potom izobrazbe i korisnika knjižnice posebice u korištenju novih informacijskih alata. Pri tome se ne zanemaruje niti utjecaj prostornog preuređenja knjižnice, što je uvjetovalo drugačiji smještaj fonda, njegovu cjelokupnu reklasifikaciju, te izradbu više novih vrsta kataloga. Pozitivne promjene koje su se dogodile u relativno kratko vrijeme, od nepuna dva desetljeća, otvaraju nove mogućnosti razvoja knjižnice. Obzirom na povijesni karakter rada korištena je historiografska metoda, te metoda analize sadržaja. Dobiveni su podatci strukturirani analitičko-sintetičkom metodom.

1 Dr.sc. Ksenija Švenda-Radeljak, viša knjižničarka, e-mail: kradelj@pravo.hr
Stručni članak

Primljeno: listopad, 2013.

Prihvaćeno: siječanj, 2014.

UDK 027.7《1994/2013《

DOI 10.3935/ljsr.v21i1.12

Ksenija Švenda

Radeljak ${ }^{1}$

Studijski centar socijalnog rada

Pravni fakultet Sveučilišta u Zagrebu

Ključne riječi:

knjižnica visokoškolske ustanove, proces informatizacije knjižnice, profesionalna izobrazba knjižničara. 


\section{UVOD}

Početak ovog razdoblja obilježava odlazak u mirovinu dugogodišnje knjižničarke Ksante Weiner, čiji je djelovanje umnogome odredilo i profiliralo razvoj knjižnice Studijskog centra socijalnog rada (dalje se u tekstu koristi i kratica SCSR) (Švenda-Radeljak, 2010.). Na radno mjesto dipl. knjižničarke dolazi Ksenija ŠvendaRadeljak, dipl. knjižničarka i dipl. socijalna radnica. Fond knjižnice dočekao je devedesete godine u premalom i skučenom prostoru, neadekvatno smješten u ormare, te time i nedostatno dostupan korisnicima. Kako bi korisnicima bile dostupne bar neke osnovne informacije o fondu, posebice o prinovama, prof. Weiner redovito je sastavljala i distribuirala unutar fakultetskih službi popis noviteta u knjižnici pod nazivom »Bilten prinova«.

Građa se formalno obrađivala, što je rezultiralo izradbom autorskog i mjesnog kataloga. Obzirom na okolnosti i niz ostalih poslova koje je obavljala Ksanta Weiner uspjela je položiti temelje rada knjižnice, koji su se nakon toga trebao razvijali i mijenjali u skladu s promjenama i u samoj ustanovi.

Promjene koje su se dogodile biti će praćene unutar dva osnovna razdoblja: 1994.-2000. godine, te od 2000. godine do danas. Godina 2000. uzima se kao svojevrsna prijelomna godina, jer je u toj godini Ministarstvo znanosti uvrstilo u klasifikaciju znanstvenih područja i polje socijalnih djelatnosti, što je otvorilo nove mogućnosti znanstvenog rada (Ajduković, 2002.). Istovremeno je to godina kada u knjižnici započinje proces informatizacije rada, uvođenjem knjižničnog sustava CROLIST .

\section{PRVE PROMJENE : 1994.-2000.}

Početak ovog razdoblja započinje smjenom djelatnika unutar knjižnice, te uvođenjem prvih novosti u organizaciju rada. Prilikom primopredaje knjižnice izvršena je ograničena revizija fonda, obzirom da zbog nedostatka vremena i osoblja nije mogla biti provedena u cjelini. Knjižnica tada nije iskazivala materijalnu vrijednost građe, te se u procesu revizije težište stavilo na otpis zastarjele i dotrajale građe. Na taj se način fizički donekle smanjio broj jedinica građe, no problem prostora ostao je i dalje prioritetan. Prostor knjižnice sastojao se od 4 sobe u nizu, te od dvije sobe u hodniku preko puta knjižnice koje su bile u funkciji spremišta ukupne kvadrature $130 \mathrm{~m}^{2}$.

\section{2 članci}




\section{Uređenje prostora}

Osnovni problem prostora nije bio u veličini, već u njegovoj neadekvatnoj iskoristivosti, obzirom na smještaj građe u običnim ormarima, a u spremište knjižnice odlagala se i građa koja nije imala nikakve veze s knjižnicom. Inicijativa preuređenja postojećeg prostora stoga se nametnula kao logičan prioritet, kako bi se fond mogao organizirati prema pravilima knjižničarske profesije. Inicijativa je naišla na vrlo dobar prijem od strane tadašnjeg predstojnika Studijskog centra socijalnog rada prof. dr. sc. Vlade Puljiza, te već u zimskom semestru ak. god. 1994./95. započinju preinake. Četiri sobe koje su činile glavni dio knjižnice prvo su okrečene, popravljeni su parketi i prozori, te u posljednje dvije postavljene standardne knjižne police 1.500 dužnih metara. Postavljanjem adekvatnih polica u jednu se prostoriju smjestila knjižna građa, kao i radni prostor knjižničara, a u drugu časopisi, koji su odvojeni na domaće i strane.

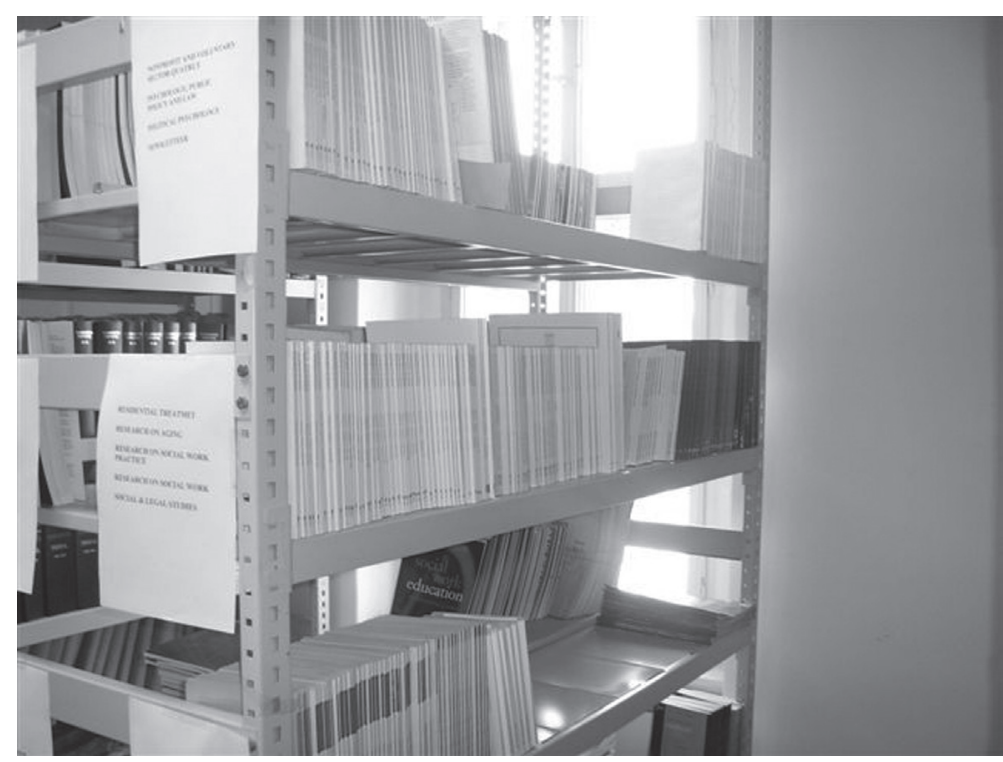

Slika 1. Police u knjižnici - soba časopisa

Prve dvije sobe predviđene su: prva kao prijemna soba za korisnike, a drugoj je namijenjena funkcija novo ustrojena skriptarnica Studija. Dvije sobe preko puta knjižnice, koje su do tada imale funkciju spremišta, uređene su kao sobe za nastavnike, a za potrebe knjižnice izvršena je adaptacija dijela tavanskog prostora od $60 \mathrm{~m}^{2}$. Taj je prostor izoliran, postavljen je drveni pod, te uređen prilaz. U prostor tavana premješteni su ormari i u njih su složeni diplomski radovi studenata koji pripadaju arhivskom dijelu knjižnice, kao i pasivni dio knjižnog fonda. 


\section{Obradba građe}

Građa knjižnice polinje se obrađivati i formalno i sadržajno. Formalna obradba knjižnične građe popisuje podatke bitne za identifikaciju određene publikacije, a njena je svrha izradba abecednog kataloga. Prema Pariškim načelima, abecedni katalog mora odgovoriti na ova pitanja: posjeduje li knjižnica određenu publikaciju koju pobliže označuje autor i stvarni naslov, ako autor nije naveden, samo stvarni naslov, koja djela određenoga autora ima knjižnica i koja izdanja određenoga djela ima knjižnica. Sadržajna obrada , čiji su rezultat stvarni (realni) katalozi: predmetni i stručni trebaju odgovoriti na korisnička pitanja o građi iz određenoga stručnog područja, kao i pitanja o određenom predmetu (Tadić, 1994.)

Fond knjižnice Studijskog centra socijalnog rada činile su knjige, časopisi i izdavačka djelatnost fakulteta (skripte) te doktorske disertacije profesora, magisteriji i diplomski radovi. U svrhu pretraživanja građe knjige su se formalno obrađivale, te je postojao autorski katalog. Naslovni je katalog bio u izradbi.

Sadržajna je obradaba tek započinjala. Predmetni je katalog bio dio plana budućeg rada knjižničarke prof. Weiner. Zamišljeno je da se kao predmetne oznake koriste oznake nazivi kolegija koje su studenti slušali, ili neka općenita znanstvena područja čiju je građu knjižnica posjedovala (npr.: socijalna politika, psihologija, pedagogija, statistika i sl.). Donja slika prikazuje plan izradbe predmetnog kataloga kolegice Weiner.

\section{4 članci}


K. Švenda-Radeljak: Knjižnica studijskog centra socijalnog rada 1994.-2013. ...

\section{$-4-$}

R - RADWO ZAKOWODAVSTYO; ODNOSI I UDRUZZENI RAD

1. Posredovanje rada (zavodi za zapošl javanje)

2. Inspeicei ja rada 1 zaštita na radu

3. Profesionalna orijentacija

4. Radni odnosi

Re - RELIGIJA

Bi - SIMDIKATI

SOC - SOCIOLOGIJA

1. Radnički pokret

2. Socijalna psihologija

3. Sociologija grada 1 naselja

4. Ruralne sociologija

5. Slobodno vrijeme 1 rekreacija, godišnji odmori

Im - SOCIJALNI RAD - METODIKA SOCIJALHOO RADA:

a) rad na slučaju

b) grupni rad

c) socijalni rad $u$ komun1

$\mathrm{Bm}_{1}$ - Teorija socijalnog rada

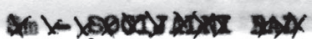

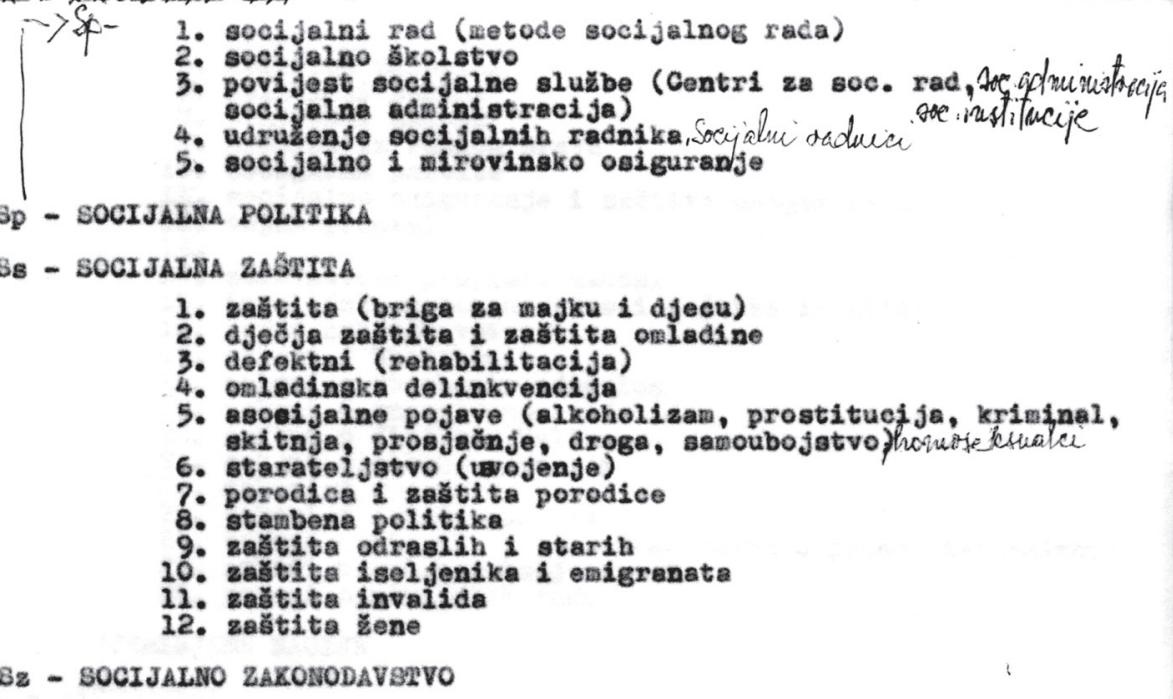

Slika 2. Plan izradbe predmetnog kataloga

No stručnog kataloga izrađenog na osnovi nekog klasifikacijskog sustava nije uopće bilo. Knjige su bile smještene prema numerusu curensu CURRENS - broju koji označava redoslijed unošenja knjige u fond knjižnice. 
Tijekom procesa fizičkog preuređenja knjižnice, djelomice je izmijenjena struktura fonda, te su skripte (koje su većim dijelom bile zastarjele ili u fizički lošem stanju) pohranjene kao pasivni dio fonda ili otpisane. Doktorski i magistarski radovi, te diplomski radovi studenata smješteni su zasebno, kao dio arhive knjižnice. Za njih se izrađuju popisi prema mentoru i temi rada. Moguće in je bilo koristiti za rad u knjižnici, što se do danas zadržalo kao dio knjižnične usluge.

Neposredno tijekom fizičkog preuređenja knjižnice, zbog obima posla nije se pristupilo izradbi stvarnih kataloga, te se građa nastavila formalno obrađivati. No obzirom na potrebe korisnika, ubrzo se pristupilo izradbi predmetnog kataloga, odnosno tzv. predmetnoj obradbi građe.

Svrha je predmetne obradbe utvrditi predmet - temu određene publikacije, ne uzimajući u pri tome u obzir stručno područje kojemu ta tema pripada. Primjerice predmet publikacije može biti »depresija«, a znanstveno područje u koje se uvrštava: »psihijatrija«.

Rezultat formalne obradbe građe je abecedni katalog, odnosno pretraživanje na osnovi autorstva, a klasifikacija ili stručna obradba pridonosi stvaranju stručnog kataloga odnosno pretraživanju unutar stručnih, unaprijed utvrđenih skupina, konačni je cilj predmetne obrade izradba predmetnog kataloga odnosno mogućnost pretraživanja fonda na osnovi predmetnica (Tadić, 1994.). U početcima rada predmetnice su bile slobodno određene. Pri njihovom odabiru koristi se postojeća stručna literatura, ključne riječi iz članaka koji se obrađuju, te znanje i procjena samog knjižničara - predmetnog stručnjaka. O daljnjem razvoju predmetnog kataloga, biti će više riječi u kasnijoj fazi rada. Pred kraj gore opisanog razdoblja, 1999. Godine, u knjižnici se zapošljava pomoćna knjižničarka Branka Krapac, koja preuzima dio poslova vezanih uz neposrednu manipulaciju građom i dio rada s korisnicima.

\section{RAZVOJ KNJIŽNICE U SLIJEDEĆEM RAZDOBLJU: 2000.- 2013.}

Sljedeće razdoblje razvoja knjižnice izuzetno je bogato brojnim promjenama, koje su djelomice bile povezane s promjenama u radu u proteklom razdoblju, a djelomice je riječ o potpuno novim uslugama knjižnice. Prva od njih bila je klasifikacija fonda, te niz poslova time povezanih. 


\section{Klasifikacija fonda i izradba stručnog kataloga}

Povećan opseg građe knjižnice, a nadasve kvalitativne promjene u samom radu Studija, nakon priznavanja polja socijalnih djelatnosti kao znanstvenog polja, nužno su vodile izgradnji stručnog kataloga, prema UDK sustavu klasifikacije. UDK je sustav sređenih pojmova unutar deset osnovnih skupina koje se obilježuju brojkama od 0 do 9. Dodavanjem još jednog broja (od 0 do 9), svaka se od glavnih skupina dalje dijeli u deset podskupina, itd. Tako se svaki pojam može raščlaniti do najsitnije pojedinosti. Poput svakoga dobro postavljena općega klasifikacijskog sustava, UDK uz glavne tablice, u kojima je razvrstano cjelokupno ljudsko znanstveno i umjetničko stvaranje, ima i pomoćne tablice (Tadić, 1994.)

UDK klasifikacija činila se najpogodnijom s obzirom na velike mogućnosti kombinacija koje pruža samom svojom strukturom. Naime socijalna djelatnost kao znanstveno polje sadrži znanstvene grane: socijalnu politiku, posebna područja socijalnog rada, socijalno planiranje, socijalnu gerontologiju i teorija i metodologija socijalnog rada. One su u raznim međusobnim odnosima koje nužno treba prikazati. Osim toga i dalje se vrši kontinuirana nabava iz srodnih područja društvenih znanosti, stoga je bilo važno uvrstiti građu u konzistentan, ali opet dovoljno elastičan sustav klasifikacije. Nije nevažna ni činjenica da je UDK klasifikacija najraširenija u knjižnicama svih vrsta u Hrvatskoj.

Obzirom da je temeljito preuređenje knjižnice bilo povezano s otpisom građe, bilo je moguće izvršiti klasifikaciju cjelokupnog fonda.

Tom se vrlo opsežnom i nadasve važnom poslu pristupilo planski u više faza:

1. utvrđena je veličina samog fonda koji će doći u obzir za klasifikaciju. Radilo se o otprilike 8.000 naslova knjižne građe prema podatcima iz abecednog kataloga i inventarnih knjiga

2. u dogovoru s tadašnjom predstojnicom SCSR-a, prof. Marinom Ajduković, knjižnica se zatvorila u vrijeme zimskih ispitnih rokova, osim za vraćanje knjiga, jer je odlučeno da se i fizički smještaj knjiga promijeni, te da umjesto prema numerusu currensu, budu i na policama složene prema UDK klasifikaciji

3. paralelno se izrađivao katalog i fizički smještala građa na police

UDK klasifikacijom znatno je pojednostavljen rad knjižničarima kako u smislu pretraživanja, tako i u smislu preglednosti same građe na policama. Najčešća skupina (prije promjena UDK) bila je skupina 36 - Socijalni rad, pomoć, stanovanje, osiguranje, te skupina 304 - Socijalna politika. Obzirom na multidisciplinarnost socijalnih djelatnosti, česta je uporaba dvotočke (:), kojom se osnovne skupine socijalnog rada i socijalne politike povezuju sa srodnim znanostima (psihologijom, pedagogijom, medicinom, sociologijom, pravom i dr.). 
Od 2004. godine počinje se primjenjivati nova preporučena klasifikacija (prema preporukama komisije za UDK iz 2000. god.) koja je integrirala socijalnu politiku i posebna područja socijalnog rada u zajedničku skupinu 36 - Socijalna skrb (prijevod engleskog izraza social welfare). Prednosti UDK klasifikacije prvenstveno su namijenjene knjižničaru, no za potrebe korisničkog pretraživanja fonda, potrebno je bilo građu klasificirati pomoću predmetne obradbe. Rezultat toga bilo je stvaranje predmetnica strukturiranih prema određenim kriterijima, i njihovo organiziranje u predmetnom katalogu.

\section{Informatizacija knjižnice}

Godine 2000. započinje informatizacija knjižnice. Nabavlja se integrirani knjižni sustav CROLIST, te kompletna vlastita hardverska konfiguracija na koju se instalira. Nabavljen je i jedan kompjutor za korisnicima knjižnice. Novi se fond odmah unosi u bazu CROLIST, dok se stari fond postepeno retroaktivno unosi, te je u slijedećih nekoliko godina čitav aktivni fond knjižnice unesen u bazu. To je omogućilo potpuno online pretraživanje fonda knjižnice Studijskog centra, ali i online kataloga ostalih knjižnica. Izrađuje se i samostalna mrežna stranica knjižnice unutar mrežnih stranica SCSR-a Pravnog fakulteta, koja sadrži ne samo informacije o knjižnici, već i mnoge poveznice na razne e-izvore informacija: http://www.pravo.unizg.hr/scsr/ knjiznica

Sve su te promjene uz ostalo, još više aktualizirale i potrebu za standardizacijom u predmetnoj obradbi građe.

\section{Izradba prvog tezaursa}

Navedene su su promjene u knjižnici korespondirale s promjenama u strukturi korisnika, koja raste i kvantitativno, ali i kvalitativno. Knjižnica postaje sve posjećenija i potrebnija, a svojim fondom, posebice izborom časopisa postaje zanimljiva i korisnicima drugih sličnih znanstvenih područja. Tako korisnički upiti postaju sve složeniji, a informacija treba biti što brža i aktualnija. Istovremeno korisnike se educira samostalnom pretraživanju elektronskih izvora informacija. Dakle, sam proces traženja informacije više nije »monopol« knjižničara, već sve više dio aktivnosti korisnika. U takvoj situaciji knjižna građa mora biti tako obrađena da korisnik na svoj upit koji je dan na prirodnom jeziku može dobiti što potpuniju informaciju. Stoga u ovoj najnovijoj fazi razvoja knjižnice predmetna obradba građe postaje vrlo važna, jer to je jedini pravi način da korisnik dobije što potpuniju informaciju na svoju upit. Povećana aktivnost korisnika u procesu pretraživanja povezana

\section{8 članci}


sa informatizacijom knjižnice, ukazala je na probleme koji uvijek prate predmetno označivanje građe, a to su problemi prirodnog jezika kao što su nestandardiziranosti, sinonimije, višestruka značenja. Ti negativni aspekti posebno su očiti kod učestalog pretraživanja po predmetnicama. Kako predmetnice nisu standardizirane, korisnici često puta ne postavljaju adekvatan upit, te tako ne dobivaju ili dobivaju polovične informacije. Nestandardiziranost predmetnica problem je i knjižničaru pri obradbi građe. Obzirom na razvitak znanstvenog područja socijalnih djelatnosti, predmetnice moraju moći pratiti njegov znanstveni jezik. Stoga knjižničari svoju predmetnu obradbu trebaju prilagođavati aktualnim promjenama samog znanstvenog područja čiju građu obrađuju. U suradnji sa znanstveno-nastavnim osobljem knjižničar kreira, upotpunjava i standardizira jezik znanstvenog područja, te time stvara umjetni jezik kontroliranog rječnika, što je jedan od uvjeta rasta i razvoja pojedine znanosti.

Imajući u vidu gore opisan razvoj kako samog područja, tako i sve složenije i povećane zahtjeve korisnika, uvidjelo se da je nužno pristupiti izradbi tezaursa za znanstveno polje socijalnih djelatnosti, kako bi se provela standardizacija jezika i omogućilo brže i efikasnije pretraživanje građe, te time i razvoj samog znanstvenog područja. Prema standardu ISO 2788-1986 (http://www.niso.org/schemas/) tezaurs je sredstvo za terminološku kontrolu, koja se koristi pri prevođenju iz prirodnog jezika dokumenta, ključnih riječi i govora korisnika u uži, dokumentacijski/ informacijski jezik. Nazivi deskriptorskog jezika omogućuju detaljno indeksiranje dokumenata i traženje informacija pomoću tih naziva. Tako tezaurus mora sadržavati sve deskriptore ko je koristi određeni sustav i iskazati njihovu pojmovnu srodnost. Mora ujedno iskazati i ključne riječi unutar sustava, koje su riječi sporednog značenja u odnosu na prihvaćene deskriptore (Švenda-Radeljak, 2005.).

No, socijalna djelatnost kao znanstveno područje vrlo je široko strukturirano po granama, koje su same po sebi kompleksne i multidisciplinarne. Stoga bi se kao prvi i najvažniji zadatak pristupilo izradbi tezaurusa za granu socijalna politika. Predmetnice dodijeljene toj grani uspješno se mogu standardizirati u deskriptore, a sama njena struktura je hijerarhijski postavljena, što olakšava izradu hijerarhijske strukture tezaurusa. Izradba i mogućnosti izradbe tezaursa za ostale grane socijalnih djelatnosti bile su tema magistarskog rada (Švenda-Radeljak, 2005.). Dugoročni je projekt izradba tezaursa i za ostale grane područja.

\section{Prostorne promjene i uređenje}

Tijekom čitavog opisanog razdoblja, vrši se stalna nabava novih knjiga, te pretplate na nove naslove časopise. Nabava se sve više specijalizira, te se postepeno 
izgrađuje fond koji teži pratiti znanstveno-nastavni rad svih područja. Postojeći prostor knjižnice postaje premalen, spremište na tavanu neadekvatno, a zbog mogućeg remećenja statike zgrade i dugoročno neodrživo. $U$ ak. godini 2001./02. preuređuje se stoga dio podruma zgrade od oko $60 \mathrm{~m}^{2} \mathrm{u}$ spremište koje dijele knjižnica i arhiv Studija. Spremište je opremljeno pomičnim policama izrađenim prema najnovijim knjižničarskim standardima. U njega se seli građa pohranjena na tavanu: stariji diplomski radovi studenata, starija godišta časopisa, arhivska građa knjižnice. Ujedno se iz središnjeg prostora knjižnice u spremište spuštaju i duplikati građe, te starija knjižna građa, čime se oslobađa prostor u kojem je smješten aktivni fonda knjižnice. Ovim velikim preuređenjem knjižnica Studijskog centra postaje jedna od rijetkih visokoškolskih knjižnica dugoročno riješenog problema prostora za smještaj građe.

\section{Edukacija osoblja knjižnice}

Osim formalne edukacije, potrebe rada u knjižnici i obveza praćenja promjena u knjižnično-informacijskom okruženju u cjelini, nameću neprekidnu cjeloživotnu edukaciju svakog zaposlenika u knjižnici. Obje stručne djelatnice knjižnice se usavršavaju svaka u svom segmentu rada. Tako je pomoćna knjižničarka ubrzo nakon zapošljavanja položila stručni ispit za pomoćnog knjižničara. Tijekom procesa informatizacije prošla je i tečaj katalogizacije u CROLISTU zajedno s dipl. knjižničarkom. Redovito polazi pojedine jednodnevne tečajeve u organizaciji Centra za stalno stručno usavršavanje knjižničara, kao i pojedine prezentacije određenih elektroničkih izvora informacija koje nabavlja Biblioteka Pravnog fakulteta, čiji je integralni dio knjižnica SCSR-a.

Diplomirana knjižničarka isto je tako pohađala povremene edukacije u organizaciji Nacionalne i sveučilišne knjižnice, te brojne stručne skupove i seminare. U cilju uspješnijeg rada i stjecanja novih znanja, upisuje i završava poslijediplomski studij informacijskih znanosti, čime stječe akademski stupanj magistra, a godine 2012. i doktora informacijskih znanosti. Tako stečeno znanje velikim dijelom koristi i na području edukacije korisnika knjižnice.

\section{Edukacija korisnika knjižnice informacijskoj pismenosti}

Informacijska pismenost definira se na razne načine, no jedna od najviše citiranih je ona autora Webbera i Johnstona koji je smještaju u širi društveni konteks: »Informacijsko se opismenjavanje sastoji se od usvajanja primjerenog informacijskog ponašanja u svrhu dolaženja do one informacije koja će zadovoljiti informacijsku po- 
trebu, i to bez obzira na medij, a uključuje i kritičku osviještenost o važnosti mudrog $i$ etičkog korištenja informacija. Važno je da informacijska pismenost ne bude reducirana na knjižnične ili računalne vještine, već poimana kao odgovor na kulturni, društveni i ekonomski razvoj informacijskog društva." (Lasić Lazić, Špiranec i Banek, 2011.)

Stoga jedna od osnovnih novih zadaća knjižničara jest i poduka korisnika svih kategorija novoj, informacijskoj pismenosti. Pri tome knjižničari postaju suradnici u procesu cjeloživotnog obrazovanja. Poduka korisnika informacijskoj pismenosti trebala bi mu omogućiti da razvije vještine i sposobnosti ne samo pronalaženja, već i kritičkog vrednovanja, a na koncu i pravilnu uporabu pronađenog. Pri tome je najmanje važno gdje je izvor informacija.

Nove generacije studenata, rođenih i (ili) odraslih u tz. »internetskom okruženju« umnogome se razlikuju od prošlih. Korištenje računala od najranije dobi svakako utječe na drugačiju percepciju znanja i njegove dostupnosti, te načina učenja. Pojavljuju se koncepti: »učenje na zahtjev (learning-in-demand), »učenje u pravo vrijeme« (just-in-time-learning), »učenje samo koliko je potrebno« (just-enough-earning) i »učenje samo za tebe." (just-for-you-learning) (prema Lisek i Brkljačić, 2012., 32). Postoji uvriježeno mišljenje o Internet generaciji koja suvereno vlada vještinama snalaženja u digitalnom okruženju. No, provedena istraživanja u svijetu to u velikoj mjeri opovrgavaju. Tako se više istraživanja (prema Lasić Lazić, Špiranec, Banek, 2011.) slaže u nekim osnovnim točkama:

- ispitanici pokazuju veliku sklonost korištenju Weba, a u traženu rješenja problemskih zadataka preferiraju Google-ovu tražilicu

- u svom su pristupu često puta površni, skloni kvantitativnom a ne kvalitativnom pristupu stranicama

- nedovoljno kritički valoriziraju ponuđene sadržaje

- nestrpljivi i površni

- ne posjeduju vještinu pretvaranja svojih potreba u informacijski upit

Većine tih problema svjesni su knjižničari iz svoje svakodnevne interakcije s korisnicima. Osim gore navedenih problema koji karakteriziraju mlađe generacije studenata, postoje problemi potpuno suprotnog predznaka. Riječ je o studentima, često starijih generacija, koji se relativno teže snalaze u informacijskom okruženju, te pokušavaju i dalje preferirati konvencionalne načine pronalaženja informacija i uobičajene metode učenja. Zbog jedne i druge krajnje kategorije, te onih studenata između toga, knjižničari već dugo vremena provode poduke korisnika u vještinama i načinima učinkovitog pretraživanja informacija, za koju se danas sve više rabi naziv informacijska pismenost. 
U ovom je radu već usput spomenuto kako je u knjižnici već s početcima informatizacije započela edukacija korisnika, kako bi postali aktivni učesnici u procesu pretraživanja i nalaženja referentnih informacija. Prve su poduke bile neselektivne i nesustavne i individualne. Najčešće su se odvijale u formi »poduke na licu mjesta«, kao odgovori na pojedinačne upite korisnika. Najviše je interes za tu vrstu novih vještina bio kod znanstveno-nastavnog osoblja - profesora, koji su pojedinačno postavljali upite, a mnogi od njih vrlo brzo usvojili osnovne vještine pretraživanja.

No i potrebe studenata za takvom vrstom poduke sve su brojnije. Stoga se u ak. god. 2003./04. od strane Uprave čitavog Pravnog fakulteta organizira sustavna poduka studenta I. godine koju izvode knjižničari Biblioteke Pravnog fakulteta i knjižnice SCSR-a. Ona se odvijala u dvoranama Pravnog fakulteta. Studenti su bili podijeljeni u grupe, osim studenata SCSR-a koji su činili zasebnu cjelinu, koja se unutar sebe dijelila u manje grupe. Broj polaznika studenata SCSR-a bio je 135 prema podacima Referade Studijskog centra socijalnog rada.

Metodologija poučavanja bila su kratka predavanja knjižničara. Studente se upoznavalo sa:

- specifičnostima knjižnice visokoškolske ustanove i njenim uslugama

- mrežnom stranicom Biblioteke Pravnog fakulteta, napose s knjižnicom SCSR-a

- uputama za pretraživanje on line kataloga knjižnice

- općim informacijama o ostalim mrežno dostupnim izvorima, imajući u vidu njihove

- eventualne želje, prijedloge i potrebe.

Sljedeće ak. god. i SCSR- a dobiva informatičku učionicu, te se od tada edukacija odvija u tom prostoru. Mijenja se i način prezentiranja, te se uvodi kraće predavanje u formi Power Point Prezentacije (PPP), a nakon toga sudionici aktivno izvode praktične vježbe na računalima. Vježbe obuhvaćaju: snalaženje na mrežnoj stranci knjižnice, vještine pretraživanja kataloga, izbor nekih mrežnih stranica koje bi mogle biti korisne za izradbu seminara (primjerice stranice Škole narodnog zdravlja, Državnog zavoda za statistiku, Narodnih novina, raznih udruga i sl.). Pružale su se i osnovne informacije o bazama podataka.

Trajanje edukacije bilo je oko 60 minuta, a studenti su se dijelili u grupe do 20 polaznika, s obzirom na broj mjesta u informatičkoj učionici. Ukupan broj polaznika bio je 139. Poduka se nazivala dosta nedefinirano i opisno: Informacije - gdje su i kako ih pronaći?

Međutim, nakon ak. godine 2004./05. ovaj vid poduke više se ne odvija. Poduka studenata ponovno postaje individualna, nesustavna i selektivna, isključivo prema interesima pojedinaca. No, njena je važnost prepoznata od strane samih

\section{2 članci}


profesora Studija, te je od ak. god. 2007./08. do danas, dio seminara kolegija Socijalna politika. Pohađanje poduke organizira se početkom II. semestra, a prisustvovanje se evidentira. Taj se model zadržao do danas.

Po istom su se modelu u akademskoj godini 2012./13. po prvi put u poduku uključili i seminaristi kolegija Uvod u psihologiju, njih 61 prema evidenciji Referade Studijskog centra socijalnog rada. S obzirom da su spomenuti kolegiji slušaju na I. godini studija, zainteresirani studenti viših godina koji nisu prošli edukaciju mogu se dobrovoljno prijaviti i slobodno prisustvovati. Na ovaj se način ponovno pokrenula sustavna poduka studenata prve godine, kao svojevrsni uvod u proces istraživačkog rada tijekom studiranja. Jedini nedostatak ove poduke je što nije definirana i propisana od strane Uprave fakulteta, već se zasniva na dogovoru s nastavnicima, svjesnim važnosti i potrebe takve edukacije.

\section{Poduka studenata poslijediplomskih studija}

Nakon priznavanja socijalnih djelatnosti kao znanstvenog polja, otvara se Poslijediplomski studij socijalnog rada. Njegova voditeljica prof. dr. sc. Marina Ajduković prepoznaje važnost vještina pronalaženja i korištenja informacija u mrežnom okruženju, te prihvaća prijedlog knjižnice o održavanju takve poduke. Prva je održana u ljetnom semestru ak. god. 2005./06. pod nazivom (koji će se zadržati nekoliko sljedećih godina) Pretraživanje informacija. Prisustvovalo je 16 polaznika. Organiziranjem specijalističkih poslijediplomskih studija iz Supervizije i Psihosocijalnog rada, prema gore prikazanom modelu, započinje poduka poslijediplomanata i tih studija. One su se odvijale tijekom ak. god. 2006./07., i u oba smjera prisutni su bili svi upisani. Nastavile su se za novoupisane polaznike i u sljedećoj ak. god. Polaznika tih specijalističkih studija bilo je između 16 i 20 po smjeru. U ak. god. 2006./07. uključuju se i poslijediplomanti specijalističkog studija Socijalna politika, njih 16 , te se poduka prilagođava specifičnim potrebama i interesima te druge značajne grane znanstvenog područja socijalnih djelatnosti. Nova generacija studenta tog specijalističkog studija u ak. god. 2008./09., isto tako prolazi poduku. Posljednja poduka poslijediplomanata održana je ak. god. 2012./13. za polaznike novog poslijediplomskog specijalističkog studija Obiteljska medijacija, kojoj je nazočilo svih 30 polaznika prema evidenciji Referade poslijediplomskih studija Studijskog centra socijalnog rada. Poslijediplomanti svih smjerova uglavnom su dolazili u punom broju, te pokazivali visok stupanj motivacije za usvajanje prezentirane građe, iako dolazak nije bio obvezan. U skladu s dobrom praksom drugih visokoškolskih ustanova, a u cilju ujednačavanja nazivlja, od ak. god. 2007./08. počinje se koristiti naziv Informacijska pismenost. 
Poduka se u pravilu održava u Informatičkoj dvorani Studija, stoga broj mjesta u njoj određuje veličinu grupe, koja nikada nije veća od 20 polaznika. Trajanje poduke bilo je od početka utvrđeno na 2x 60 minuta, s pauzom. Sastoji se od PPP-a (cca 30-min), a nakon toga slijedi interaktivna radionica, gdje polaznici praktično vježbaju osnove pretraživanje prezentiranih izvora informacija u elektronskom obliku. Niže je prikazana forma poduke, koja se uz manje izmjene, zadržala do danas. Bitno je naglasiti da se pri izboru primjera za pretraživanje polazi od konkretnih tema istraživanja koje polaznici provode ili sugestija nastavnika na smjeru određenog doktorskog ili specijalističkog poslijediplomskog studija, a i sami polaznici mogu izabrati neku od tema vezanih za područje koje istražuju.

Okvirni primjer:

PPP (Power Point Prezentacija):

- djelatnosti i usluge koje korisnici mogu tražiti od visokoškolske knjižnice općenito, te

- kratko predstavljanje knjižnice Pravnog fakulteta i specifičnosti knjižnice SCSR-a

- informacije o pretraživanju općenito i vrstama kataloga

- ukratko o pojmovima koji se susreću pri pretraživanju e-izvora, te prednosti i nedostaci

- raznih e-izvora (primjerice komparacija Googla s nekom bazom znanstvenih podataka)

- predstavljanje relevantnih domaćih el. izvora (Narodnih novina, Hrvatske znanstvene

- bibliografije, ponudu Državnog zavoda za statistiku i sl.)

- predstavljanje e-baza prema dogovoru s polaznicima, s posebnim naglaskom na e-časopise (EBSCO kazalo »A to Z«)

Radionica:

- vježba pretraživanja e-kataloga knjižnice SCSR-a na zadani pojam, prema odabiru sudionika, kao primjer kataloga

- vježba pretraživanja nekih domaćih el. izvora, u skladu sa željama i potrebama sudionika

- vježba upoznavanja i kratkog pretraživanja baza od značaja za poslijediplomski studij koji trenutno polaze, posebice e-časopisa. 


\section{ZAKLJUČAK}

U nepuna dva desetljeća u knjižnici Studijskog centra socijalnog rada (SCSRa) dogodile su se značajne promjene, koje su u velikoj mjeri promijenile njenu strukturu rada i djelovanja. Podudarale su se s promjenama organizacije Studija, te promjenom percepcije šire javnosti o socijalnim djelatnostima. Sve su one bile međusobno povezane, te jedna promjena proizlazila iz druge, a konačni je rezultat razvoj knjižnice prema suvremenoj knjižnici visokoškolske ustanove koja može biti ravnopravni sudionik u nastavno-znanstvenim procesima Studija.

\section{LITERATURA}

1. Ajduković, M. (2002). Poslijediplomski studij iz teorije i metodologije socijalnog rada. U: Ajduković, M. (ur.), 50 godina Studija za socijalni rad: 1952. - 2002. Zagreb: Studijski centar socijalnog rada Pravnog fakulteta Sveučilišta u Zagrebu, 99-103.

2. Lasić-Lazić, J., Špiranec, S. \& Banek, M. (ur.) (2011.) Izgubljeni u novim obrazovnim okruženjima - pronađeni u informacijskom opismenjavanju. U: Svi putevi vode na Internet: zbornik radova. Rijeka: Carnet Users Conference. Preuzeto s: http://cuc.carnet.hr/2011/dokumenti (12.06.2013.).

3. Lisek, J. \& Brkljačić, T. (2012). Tko nam to dolazi? Korištenje informacijske i komunikacijske tehnologije (ICT) i stilovi učenja kod novoupisanoga naraštaja studenata FER-a. Vjesnik bibliotekara Hrvatske, 55 (3/4), $29-52$.

4. Švenda-Radeljak, K. (2005). Ustroj tezaurusa za znanstveno područje socijalne djelatnosti - grana socijalna politika. Magistarski rad. Zagreb : Filozofski fakultet Sveučilišta u Zagrebu.

5. Švenda-Radeljak, K. (2010). Knjižnica Studijskog centra socijalnog rada: Razvoj do procesa informatizacije. Ljetopis socijalnog rada, 17 (1), 129-147.

6. Tadić, K. (1994). Rad u knjižnici: Priručnik za knjižničare. Opatija: Naklada Benja.

\section{MREŽNI IZVORI}

1. ISO standard 2788-1986. Preuzeto s: http://www.niso.org/schemas/ (16.09.2013.).

2. Pravni fakultet Sveučilišta u Zagrebu. Preuzeto s: http://www.pravo.unizg.hr/ scsr/knjiznica (15.09.2013.). 
Ljetopis socijalnog rada 2014., 21 (1), 153-168 str.

Ksenija Švenda-Radeljak

University of Zagreb, Faculty of Law

Department of Social Work

\section{LIBRARY OF THE DEPARTMENT OF SOCIAL WORK FROM 1994 TO 2013: DEVELOPMENT INTO A CONTEMPORARY LIBRARY}

\section{SUMMARY}

This paper presents the development of the library of the Department of Social Work at the Faculty of Law of the University of Zagreb in the period from 1994 to 2013. The period witnessed changes in the modes of work in the library caused by qualitative and quantitative changes in the institution itself. The paper in particular emphasises the informatizational process of the library which initiated many other changes in the library's functioning. Furthermore, the process of the professional training and subsequently the education of library users according to their needs are explained. The influence of spatial arrangement changes in the library (which also dictates different accommodation of the library collections, reclassification of the entire collection and the construction of many different new kinds of catalogues) is also mentioned in this paper.

Positive changes that happened during the very short time period have opened new possibilities for the development of the library. In this paper the historiographical method and the content analysis method are used and the data are structured using the analytic-synthetic method.

Key words: faculty library, informatizational proces of the library, professional training of librarians. 